\title{
Button battery ingestions in children
}

\author{
Amy R. Zipursky MD, Savithiri Ratnapalan MBBS PhD
}

Cite as: CMAJ 2021 September 27;193:E1498. doi: 10.1503/cmaj.210572

\section{Injuries in children from ingesting button batteries are \\ increasing}

Between 1999 and 2019, the United States National Poison Data System reported a $66.7 \%$ increase in yearly ingestion of button batteries (6.98 to 10.46 per million population) and a 10 -fold increase in complications $(0.77 \%[n=76]$ to $7.53 \%[n=551]) .{ }^{1}$ Button batteries can cause substantial tissue damage within 2 hours of ingestion. ${ }^{2}$

\section{The type and size of the ingested battery influence the likelihood of complications}

Lithium batteries (given their high voltage) and those $20 \mathrm{~mm}$ or larger (which are likely to become lodged in the esophagus) are most dangerous, especially in children younger than 6 years. ${ }^{2}$ Complications include gastrointestinal perforation, aortoesophageal fistulas and strictures. ${ }^{2,3}$

\section{3}

Urgency of management depends on the location of the battery

Anterior-posterior and lateral radiographs of the chest and abdomen can determine the location of the button battery. Batteries in the esophagus should immediately be removed endoscopically. Management of batteries distal to the lower esophageal junction depends on patient age and size of the battery. If the child is younger than 5 years and the battery is $20 \mathrm{~mm}$ or larger, urgent removal is recommended. Otherwise, patients can be observed as outpatients for passage of the battery in the stool. If the battery does not pass, or if symptoms develop, imaging should be repeated (at $48 \mathrm{~h}$ if the battery is $>20 \mathrm{~mm}$; at $10-14 \mathrm{~d}$ if $<20 \mathrm{~mm}$ ) and endoscopic removal considered. ${ }^{3}$

Honey or sucralfate should be administered after battery ingestion

Honey should be administered before the patient reaches the hospital, and sucralfate when in hospital within 12 hours of battery ingestion, to mitigate tissue injury while awaiting possible definitive management. Animal studies have shown that these treatments result in fewer full-thickness injuries and less extension of injury. ${ }^{4}$ Honey can be given at $10 \mathrm{~mL}$ every 10 minutes for children older than 1 year (up to 6 doses) and sucralfate can be given at $1 \mathrm{~g}$ every 10 minutes (up to 3 doses). ${ }^{4,5}$

5 Children should be monitored for long-term complications Injuries from button battery ingestion can occur despite removal of the battery; injuries such as strictures and fistulas have been reported weeks to months after removal. ${ }^{5}$ Caregivers should monitor for symptoms including gastrointestinal bleeding and vomiting.

\section{References}

1. Button Battery Ingestion Statistics. Washington (DC): National Capital Poison Center. Available: www.poison.org/ battery/stats (accessed 2021 Feb. 28).

2. Varga Á, Kovács T, Saxena AK. Analysis of complications after button battery ingestion in children. Pediatr Emerg Care 2018;34:443-6

3. Kramer RE, Lerner DG, Manfredi M, et al. North American Society for Pediatric Gastroenterology, Hepatology, and Nutrition Endoscopy Committee. Management of ingested foreign bodies in children: a clinical report of the NASPGHAN Endoscopy Committee. J Pediatr Gastroenterol Nutr 2015; 60:562-74.

4. Anfang RR, Jatana KR, Linn RL, et al. pH-neutralizing esophageal irrigations as a novel mitigation strategy for button battery injury. Laryngoscope 2019;129:49-57.

5. Mubarak A, Benninga MA, Broekaert I, et al. Diagnosis, management, and prevention of button battery ingestion in childhood: a European Society for Paediatric Gastroenterology Hepatology and Nutrition position paper. J Pediatr Gastroenterol Nutr 2021;73:129-36.

\section{Competing interests: None declared.}

This article has been peer reviewed.

Affiliations: Division of Pediatric Emergency Medicine (Zipursky, Ratnapalan), Hospital for Sick Children; Dalla Lana School of Public Health (Ratnapalan), University of Toronto, Toronto, Ont.

Content licence: This is an Open Access article distributed in accordance with the terms of the Creative Commons Attribution (CC BY-NC-ND 4.0) licence, which permits use, distribution and reproduction in any medium, provided that the original publication is properly cited, the use is noncommercial (i.e., research or educational use), and no modifications or adaptations are made. See: https://creativecommons. org/licenses/by-nc-nd/4.0/

Correspondence to: Amy Zipursky, amy.zipursky@sickkids.ca

CMAJ invites submissions to "Five things to know about ..." Submit manuscripts online at http://mc. manuscriptcentral.com/cmaj 